\title{
Analysis by pulsed-field gel electrophoresis of insertion mutations in the transferrin-binding system of Haemophilus influenzae type b
}

\author{
R. CURRAN, K. R. HARDIE and K. J. TOWNER* \\ Department of Microbiology and PHLS Laboratory, University Hospital, Queen's Medical Centre, \\ Nottingham NG7 $2 \mathrm{UH}$
}

\begin{abstract}
Summary. A mutagenesis system involving the insertion of a non-transposable antibiotic resistance gene cassette was used to generate stable mutations in the chromosome of Haemophilus influenzae type b strain Eagan. The mutations generated were shown by pulsedfield gel electrophoresis (PFGE) to have unique SmaI fingerprint patterns and to be located randomly on the chromosome. Of 700 insertion mutants screened, 29 had stable insertions resulting in constitutive expression of transferrin-binding proteins (TBPs). The high proportion of such mutants indicated that numerous regulatory loci could influence the expression of this phenotype. Five such regulatory mutations were analysed in detail by PFGE and DNA hybridisation and were shown to be located at five different chromosomal loci, although three of the five loci were located on the same 330-kb SmaI fragment of the wild-type strain Eagan chromosome. This fragment also contains several important virulence determinants, including the capb locus, and one of the five constitutive mutants had concomitantly lost the ability to synthesise a type-b capsule. No DNA homology was demonstrated between $H$. influenzae chromosomal fragments separated by PFGE and DNA probes for the TBPs from Neisseria meningitidis, but the possibility of shared regulatory mechanisms controlling the expression of TBPs in these two species remains to be investigated.
\end{abstract}

\section{Introduction}

To cause infection, an organism must first acquire sufficient essential nutrients to multiply in vivo. One such nutrient is iron, and the low concentration of free iron on the mucous membranes and in tissue fluids is one of the first lines of host defence against bacterial infection. ${ }^{1}$ Certain pathogens, notably Neisseria meningitidis and Haemophilus influenzae type b, are capable of obtaining the necessary iron for growth in serum and cerebrospinal fluid (CSF) by means of a siderophore-independent direct interaction between host iron-binding glycoproteins, such as transferrin, and bacterial cell surface receptors (transferrin-binding proteins; TBPs).$^{2-5}$ So far as $H$. influenzae type $b$ is concerned, the transferrin receptor is thought to consist of at least two proteins - a high $\mathrm{M}_{\mathrm{r}}$ protein of c. $100 \mathrm{kDa}$ (TBP1) and a lower $\mathrm{M}_{\mathrm{r}}$ protein (TBP2) that varies from $c .70$ to $90 \mathrm{kDa}$ depending on the strain examined. ${ }^{3.6 .7}$ Although transferrin-binding ability has been detected in a range of haemophili, the presence of this property, while not a universal characteristic, is associated strongly with $H$. influenzae type $b$ isolates from invasive infections. ${ }^{5}$ The possible

Received 13 Jan. 1994; accepted 11 Feb. 1994

* Correspondence should be sent to Dr K. J. Towner. existence of shared antigenic domains in the TBPs of $H$. influenzae and $N$. meningitidis, albeit only in the very limited number of strains so far examined, ${ }^{8}$ has suggested that TBPs might form useful components of a single vaccine active against the two main causes of bacterial meningitis.

Expression of TBPs in laboratory-adapted isolates of $H$. influenzae type b occurs only when iron is absent from the growth medium. ${ }^{6}$ In contrast, examination of a large number of fresh clinical isolates from the blood and CSF of patients with meningitis has shown that a large proportion express TBPs constitutively, i.e., even in the presence of excess free iron. ${ }^{5}$ Therefore, it appears that the selective pressure of growth in the iron-restricted environment of blood or CSF may result in a regulatory switch leading to constitutive expression of the TBPs. Previous work ${ }^{9}$ has shown that conjugative transfer of transposon $\operatorname{Tn} 916$ can be used to produce insertion mutations in this regulatory system, but such Tn916 insertions appear to lack sufficient stability for extensive genetic analysis (unpublished results). The aim of the present study was to devise an alternative insertional mutagenesis procedure that would generate stable mutants in this regulatory system, and to analyse the genetic organisation of the mutants generated by means of pulsed-field gel electrophoresis. 


\section{Materials and methods}

\section{Bacteria and media}

All experiments were performed with $H$. influenzae type b, strain Eagan. This strain was originally an invasive clinical isolate ${ }^{10}$ but, following laboratory adaptation, now shows transferrin-binding ability only when grown in iron-depleted conditions. ${ }^{9}$ Insertion mutants of strain Eagan were isolated and screened as described below. Wild-type strain Eagan was grown routinely at $37^{\circ} \mathrm{C}$ on chocolate blood agar or in Brain Heart Infusion Broth (BHI; Oxoid CM225) supplemented with protoporphyrin IX (PPIX; Sigma) $0.5 \mathrm{mg} / \mathrm{L}$ and nicotinamide adenine dinucleotide (NAD; Sigma) $2 \mathrm{mg} / \mathrm{L}$ (sBHI). Strains were serotyped in a slide agglutination assay with type $b$ specific antiserum (Difco). All strains were stored at $-70^{\circ} \mathrm{C}$ in $\mathrm{sBHI}$ containing glycerol $10 \% \mathrm{v} / \mathrm{v}$.

\section{Isolation of ribostamycin-resistant insertion mutations}

The method used was based on that of Vosman et $a l .{ }^{11}$ in which a non-transposable antibiotic resistance gene cassette is ligated in vitro to random chromosomal fragments. Following transformation into a host cell, the resistance gene cassette is inserted randomly into the chromosome by means of normal recombinational events with the corresponding homologous chromosomal regions. For the present study, the nptII gene from plasmid $\mathrm{pUC} 4 \mathrm{~K},{ }^{12}$ conferring resistance to kanamycin and ribostamycin, was isolated as a $1 \cdot 3-\mathrm{kb}$ BamHI fragment from an agarose gel. Total chromosomal DNA of strain Eagan, isolated as described previously, ${ }^{5}$ was cleaved simultaneously with the restriction endonucleases $B a m \mathrm{HI}, B g / I \mathrm{I}$ and $B c / I$ to yield compatible ends on DNA fragments ranging in size from c. $5 \mathrm{~kb}$ to $<0.5 \mathrm{~kb}$. Restricted chromosomal DNA was mixed with the isolated DNA fragment carrying the $n p t I I$ gene in a $1: 1$ molar ratio and ligated (overnight at room temperature) at a final DNA concentration of $50 \mu \mathrm{g} / \mathrm{ml}$. After ligation, the recombinant DNA molecules (comprising circular molecules made up of a random chromosomal DNA fragment ligated to the $n p t I I$ gene) were transformed ${ }^{13}$ into cells of strain Eagan made competent by the MIV procedure. ${ }^{13}$ After transformation, $5 \mathrm{ml}$ of sBHI were added to each $1-\mathrm{ml}$ portion of transformed cells and incubation was continued at $37^{\circ} \mathrm{C}$ for $2 \mathrm{~h}$ to allow phenotypic expression of the nptII gene. The transformed cells were then plated on to chocolate blood agar containing ribostamycin (Sigma) $15 \mathrm{mg} / \mathrm{L}$. and incubated at $37^{\circ} \mathrm{C}$. Ribostamycin-resistant colonies were purified by re-streaking on the same medium and were then stored at $-70^{\circ} \mathrm{C}$ in $\mathrm{sBHI}$ containing glycerol $10 \% \mathrm{v} / \mathrm{v}$.

\section{Screening of insertion mutations}

Dot-blots of total chromosomal DNA from ribostamycin-resistant mutants were prepared as de- scribed previously. ${ }^{5}$ The transferrin-binding ability of mutants was examined with a solid-phase dot enzyme assay, ${ }^{5}$ after growth in either sBHI containing $40 \mu \mathrm{M}$ $\mathrm{FeSO}_{4}$ (iron-enriched medium) or sBHI containing $25 \mu \mathrm{m}$ ethylenediamine di- $o$-hydroxyphenylacetic acid (Sigma) (iron-deficient medium), ${ }^{5}$ and was recorded as either "constitutive" (binding in the presence or absence of iron), "inducible" (binding only in the absence of iron), or "non-binding" (non-inducible). The stability of insertion mutations in the transferrinbinding system (i.e., those mutants showing a phenotype other than "inducible") was investigated by growing them overnight at $37^{\circ} \mathrm{C}$ in $10 \mathrm{ml}$ of ribostamycin-free sBHI. Dilutions of these cultures were spread on to plates of chocolate blood agar. After incubation at $37^{\circ} \mathrm{C}$, single colonies were checked for retention of ribostamycin resistance by replica plating on to chocolate blood agar containing ribostamycin $15 \mathrm{mg} / \mathrm{L}$. Retention of the altered transferrin-binding phenotype was checked by repeating the solid-phase dot enzyme assay with colony lifts on to nitrocellulose membranes. ${ }^{9}$ Direct linkage between the inserted nptII gene cassette and an altered transferrin-binding phenotype was examined by isolating total chromosomal DNA from insertion mutants as described previously, ${ }^{5}$ transforming competent wild-type cells as described above, and screening ribostamycin-resistant transformants with the solid-phase dot enzyme assay.

\section{Preparation of intact chromosomal DNA in agarose plugs}

A $0.5-\mathrm{ml}$ portion of an overnight sBHI culture was inoculated into $20 \mathrm{ml}$ of fresh $\mathrm{sBHI}$ in a $200-\mathrm{ml}$ conical flask and grown on an orbital shaker $(200 \mathrm{rpm})$ at $37^{\circ} \mathrm{C}$ to $\mathrm{OD}_{650} 0.5\left(\right.$ c. $\left.5 \times 10^{9} \mathrm{cfu} / \mathrm{ml}\right)$. The cells were chilled on ice and c. $5 \times 10^{10} \mathrm{cfu}$ were pooled after centrifugation in $1.5-\mathrm{ml}$ microcentrifuge tubes for $1 \mathrm{~min}$ at $13000 \mathrm{~g}$. The final cell pellet was resuspended in $1 \mathrm{ml}$ of $\mathrm{SB}$ buffer $(1 \mathrm{M} \mathrm{NaCl}, 10 \mathrm{~mm}$ Tris- $\mathrm{HCl}$, $\mathrm{pH} 7.5$ ) at $4^{\circ} \mathrm{C}$, re-centrifuged, resuspended finally in $1 \mathrm{ml}$ of fresh SB, and held at $37^{\circ} \mathrm{C}$. Each $1-\mathrm{ml}$ cell suspension was then mixed with $1 \mathrm{ml}$ of molten (cooled to $40^{\circ} \mathrm{C}$ ) LMP Agarose (Gibco-BRL) $2 \% \mathrm{w} / \mathrm{v}$ in distilled water. The mixture was micropipetted immediately into the wells of a perspex plug mould (BioRad) and cooled to $4^{\circ} \mathrm{C}$ to allow the agarose to set. Each set of plugs was then ejected from the mould into $7-\mathrm{ml}$ plastic vials (Sterilin) containing $2 \mathrm{ml}$ of LB buffer-10 mm Tris-HCl, pH 7.5. $1 \mathrm{~m} \mathrm{NaCl}, 100 \mathrm{~mm}$ EDTA, polyoxyethylene 20 cetyl ether (Sigma) $0.5 \%$ $\mathrm{w} / \mathrm{v}$, sodium deoxycholate $(\mathrm{BDH}) 0.2 \% \mathrm{w} / \mathrm{v}, n-$ lauroylsarcosine (Sigma) $0.5 \% \mathrm{w} / \mathrm{v}$, autoclaved at $121^{\circ} \mathrm{C}$ for $15 \mathrm{~min}$. Lysozyme (Sigma) and ribonuclease A (Sigma) were added from stock solutions to give final concentrations of $1 \mathrm{mg} / \mathrm{ml}$ and $20 \mu \mathrm{g} / \mathrm{ml}$, respectively, and the vials were incubated overnight on their sides at $37^{\circ} \mathrm{C}$ with gentle shaking. The LB buffer was then replaced with $2 \mathrm{ml}$ of $\mathrm{PB}$ buffer ( $0.5 \mathrm{M}$ EDTA, pH 9.0, $n$-lauroylsarcosine $1 \% \mathrm{w} / \mathrm{v}$, proteinase $\mathrm{K}$. 
Sigma, $1 \mathrm{mg} / \mathrm{ml}$ ) and incubated at $50^{\circ} \mathrm{C}$ for $48 \mathrm{~h}$ with gentle shaking. At the end of this period, the plugs were transferred to $20-\mathrm{ml}$ plastic vials (Sterilin) containing $20 \mathrm{ml}$ of PMSF buffer, comprising $1 \mathrm{~mm}$ phenylmethylsulphonyl fluoride (Sigma) in TE (10 mM Tris- $\mathrm{HCl}, \mathrm{pH} 7 \cdot 5,0 \cdot 1 \mathrm{~mm}$ EDTA) and incubated at room temperature with gentle shaking for a minimum of $2 \mathrm{~h}$. This wash step was repeated once with fresh PMSF buffer, followed by three washes for a minimum of $2 \mathrm{~h}$ each in TE. The plugs were then stored at $4^{\circ} \mathrm{C}$ in TE until required.

\section{Digestion of DNA in agarose plugs}

Generally, digests were performed with the DNA contained in about one-third of a complete plug. Each plug portion was transferred to a sterile microcentrifuge tube and equilibrated at $30^{\circ} \mathrm{C}$ in $100 \mu$ of the $S m a$ I digestion buffer recommended by the enzyme manufacturer (Northumbria Biologicals). After $2 \mathrm{~h}$, the buffer was replaced with $100 \mu \mathrm{l}$ of fresh digestion buffer and $12 \mathrm{U}$ of $S m a \mathrm{I}$ was added. After overnight digestion at $30^{\circ} \mathrm{C}, 500 \mu \mathrm{l}$ of inactivation buffer $(0.5 \mathrm{M}$ EDTA, pH 9.0, $n$-lauroylsarcosine $1 \% \mathrm{w} / \mathrm{v}$ ) were added. The digested plugs were heated to $50^{\circ} \mathrm{C}$ for $2 \mathrm{~h}$ immediately before electrophoresis.

\section{Pulsed-field gel electrophoresis (PFGE)}

PFGE was performed in $0.5 \times \mathrm{TBE}$ buffer (TBE is $89 \mathrm{~mm}$ Tris, $89 \mathrm{~mm}$ boric acid, $2 \mathrm{~mm}$ EDTA) in a contour-clamped homogeneous electric field (CHEFDR II apparatus; BioRad). Portions of agarose plugs containing SmaI-digested DNA were loaded directly into the wells of an agarose $(1 \% \mathrm{w} / \mathrm{v}$ in $0.5 \times \mathrm{TBE})$ $14 \times 13 \mathrm{~cm}$ slab gel and sealed in place with molten agarose. Lambda oligomers (BioRad) were used as standard size markers. Electrophoresis was for $30 \mathrm{~h}$ at $12^{\circ} \mathrm{C}$ at $200 \mathrm{~V}$ with a ramped pulse time of $1-26 \mathrm{~s}$. After electrophoresis, gels were stained for $45 \mathrm{~min}$ with ethidium bromide $0.5 \mathrm{mg} / \mathrm{L}$ in $1 \times \mathrm{TBE}$ and then de-stained briefly with distilled water. DNA bands were visualised on a TM-36 UV Transilluminator (Ultra-Violet Products, Inc., San Gabriel, CA, USA) and photographed through a red filter with Polaroid Type 667 Film.

\section{Transfer of DNA from PFGE gels to nylon membranes}

PFGE gels were washed twice at room temperature with gentle shaking in each of the following solutions: (i) depurination buffer $(0.25 \mathrm{M} \mathrm{HCl}), 15 \mathrm{~min}$ each wash; (ii) denaturation buffer $(0.5 \mathrm{M} \mathrm{NaOH}, 1 \mathrm{M}$ $\mathrm{NaCl}$ ), 15 min each wash; and (iii) neutralisation buffer $(1 \mathrm{~m}$ Tris-HCl, $\mathrm{pH} 8 \cdot 0,0.6 \mathrm{M} \mathrm{NaCl}), 30$ min each wash. After a brief rinse in distilled water followed by $10 \times \mathrm{SSC}(1 \times \mathrm{SSC}$ is $150 \mathrm{~mm} \mathrm{NaCl}, 15 \mathrm{~mm}$ sodium citrate, $\mathrm{pH} 7 \cdot 0$ ), the gel was placed on Whatman $3 \mathrm{MM}$ filter paper saturated with $10 \times \mathrm{SSC}$ and exposed to a
UV light dose of $60 \mathrm{~mJ} / \mathrm{cm}^{2}$ at a wavelength of $254 \mathrm{~nm}$ in a Stratalinker UV Crosslinker (Stratagene, Cambridge). The DNA bands were then transferred to nylon membranes (Hybond-N; Amersham) with a Capillary Blotting Unit (Scotlab, Coatbridge, Strathclyde) used in an overnight transfer reaction with $20 \times \mathrm{SSC}$ as the transfer buffer. After a subsequent brief rinse in $10 \times \mathrm{SSC}$, both sides of the membrane were exposed to UV light $\left(120 \mathrm{~mJ} / \mathrm{cm}^{2}\right.$ at $\left.254 \mathrm{~nm}\right)$ to cross-link the transferred DNA to the membrane. The membrane was then air-dried and stored between two sheets of $3 \mathrm{MM}$ filter paper until required in hybridisation experiments.

\section{Hybridisation experiments}

The following DNA probes were used: (i) the $1 \cdot 3-\mathrm{kb}$ Bam HI fragment of pUC4K ${ }^{12}$ that encodes the nptII gene; (ii) the $2 \cdot 9-\mathrm{kb} B a m \mathrm{HI} / H$ indIII fragment of pG4. $2^{14}$ that encodes TBP1 from $N$. meningitidis; and (iii) the $2 \cdot 1-\mathrm{kb}$ EcoRI/HindIII fragment from pSD. $16^{15}$ that encodes TBP2 from $N$. meningitidis. DNA fragments forming probes were prepared and purified as described previously ${ }^{16}$ and were then labelled with digoxigenin-11-dUTP in a randomprimed reaction (DIG DNA Labelling and Detection Kit; Boehringer Mannheim). For hybridisation experiments, dot-blots of total chromosomal DNA and capillary blots of DNA fragments transferred from PFGE gels were first rehydrated in $2 \times$ SSC. Prehybridisation $(6 \mathrm{~h})$, hybridisation (overnight), both at $42^{\circ} \mathrm{C}$, and detection of positive hybridisation results, were all performed with the conditions, protocols and buffers recommended by Boehringer Mannheim, except that heparin (Sigma) $100 \mu \mathrm{g} / \mathrm{ml}$ was included in the pre-hybridisation and hybridisation buffers to reduce the background signal.

\section{Results}

\section{Isolation of insertion mutations in the $H$. influenzae chromosome}

The nptII gene from pUC4K was ligated to random chromosomal fragments of $H$. influenzae strain Eagan, and then transformed into competent wild-type cells of strain Eagan. Approximately 200 ribostamycinresistant transformants (c. $2 \times 10^{-7}$ transformants/ competent cell) were obtained on each plate of selective agar after insertion of the nptII gene cassette into the wild-type chromosome as a result of normal recombination between the chromosome and a random chromosomal fragment ligated to the nptII gene. No transformants were obtained in control transformation experiments with the unligated nptII DNA fragment.The presence of the $n p t I I$ gene cassette in ribostamycin-resistant transformants was confirmed (fig. 1) by preparing dot-blots of total chromosomal DNA from transformants and hybridising these with 


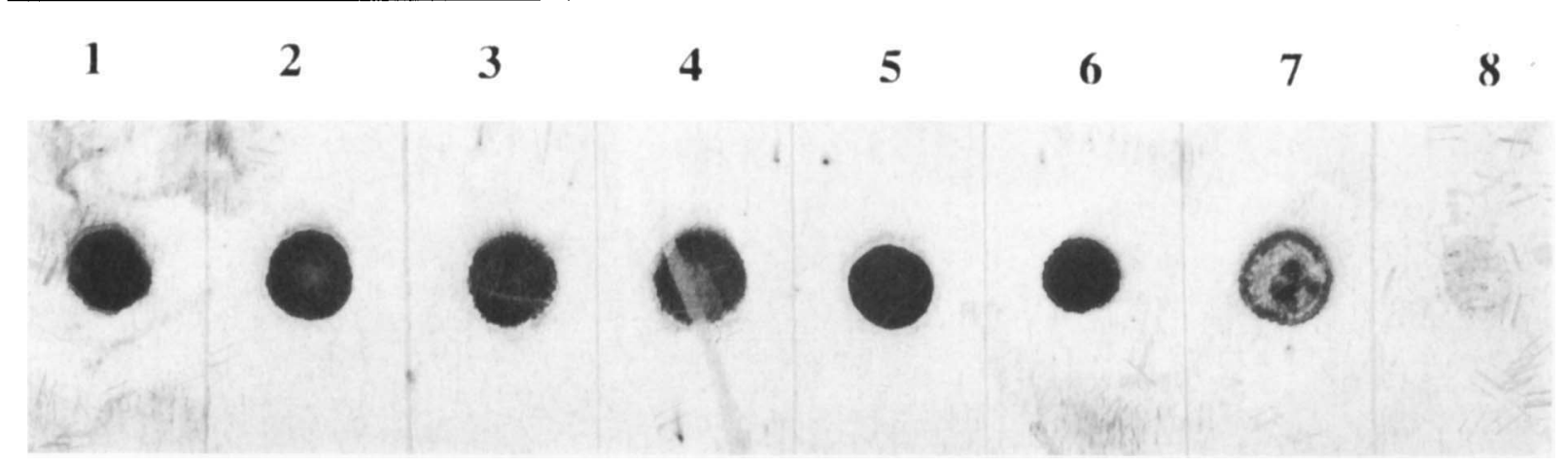

Fig. 1. Dot-blot after hybridisation of the DIG-labelled 1-3-kb BamHI fragment of pUC4K with total chromosomal DNA from (tracks 1-7) randomly-selected $n p t I I$ insertion mutants of $H$. influenzae type b strain Eagan and (track 8) wild-type strain Eagan.

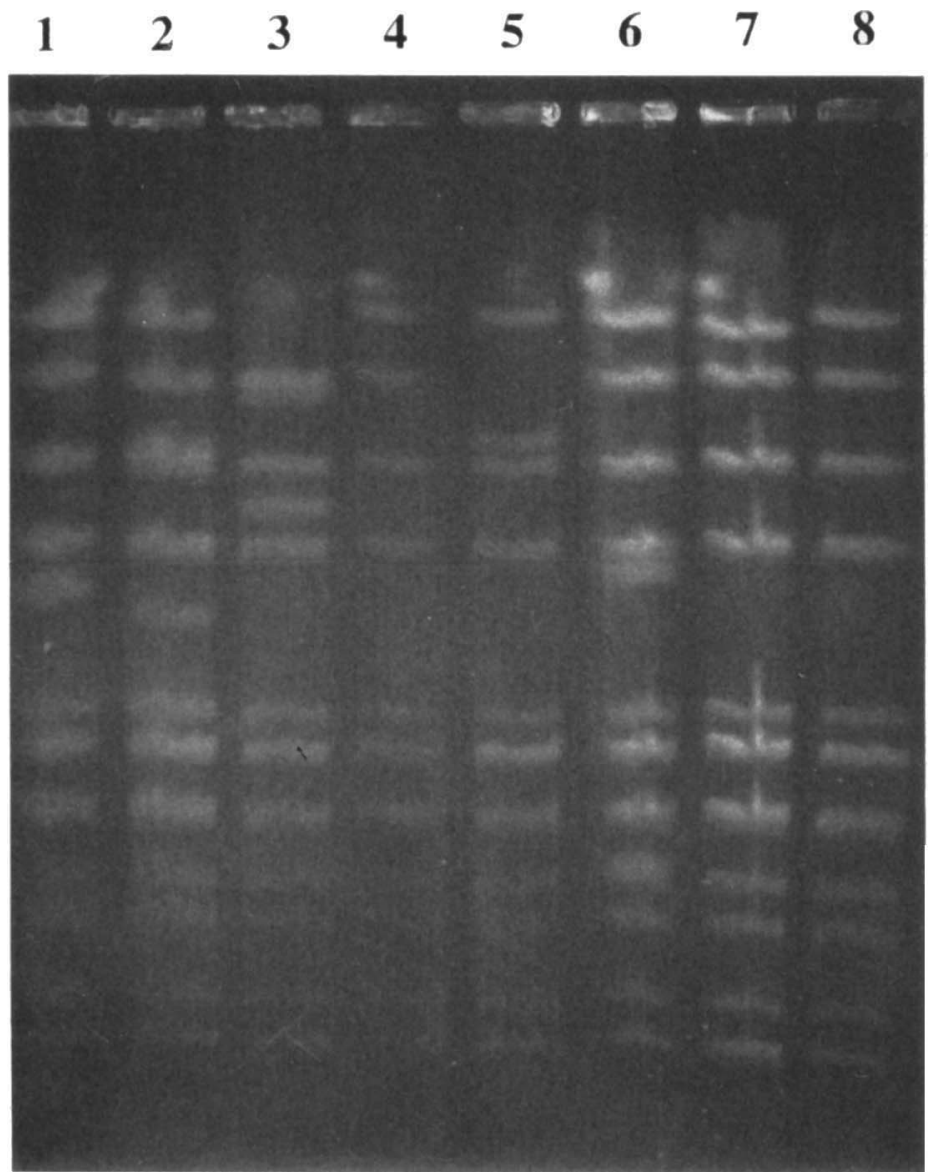

Fig. 2. PFGE analysis of SmaI chromosomal fragments derived from (tracks 1-7) randomly-selected nptII insertion mutants of $H$. influen-ae type b strain Eagan and (track 8) wild-type strain Eagan.

the DIG-labelled 1.3-kb BamHI fragment of pUC4K. When six randomly-selected insertion mutants were tested for their stability by growth in ribostamycinfree $\mathrm{sBHI}$, none of over 1000 colonies derived from each mutant tested had lost ribostamycin resistance.

\section{Random nature of insertion mutations}

SmaI is a "rare-cutting" restriction endonuclease that has been used previously in conjunction with PFGE to map the chromosome of $H$. influenzae strain Eagan. ${ }^{17}$ As the nptII gene cassette contains a single internal SmaI restriction site, ${ }^{18}$ digestion of intact chromosomal DNA with SmaI, followed by analysis with PFGE, can be used to examine the nptII insertion site in each mutant. As illustrated in fig. 2, each of the insertion mutants examined had a unique change to its SmaI fingerprint pattern, indicating that insertion of the $n p t I I$ gene cassette was occurring at random sites in the wild-type chromosome.

Screening for insertions in the transferrin-binding regulatory system

In total, 700 insertion mutants were screened for an altered transferrin-binding phenotype after growth in iron-enriched or iron-deficient medium. Six mutants were identified initially as being "non-binding", but 


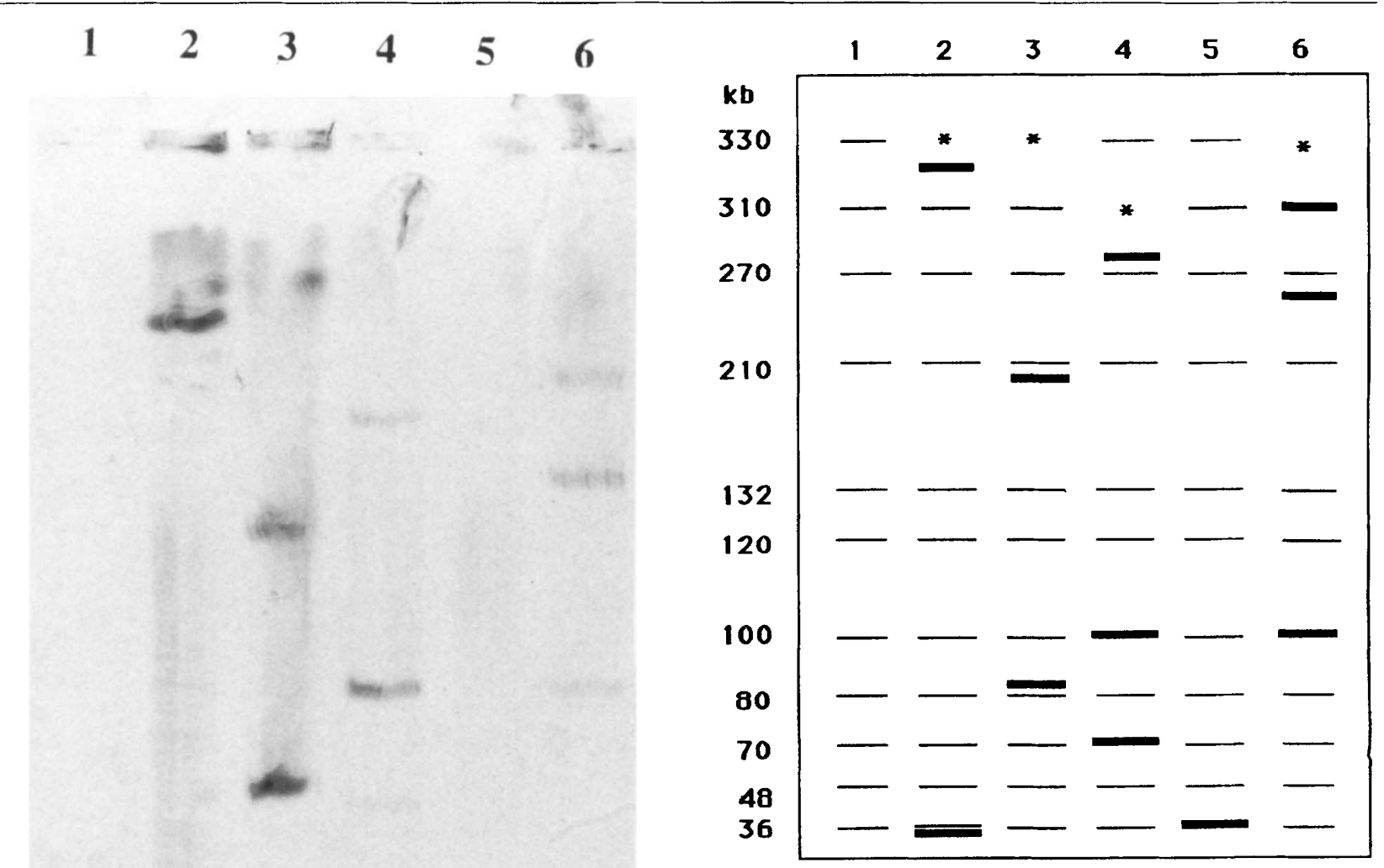

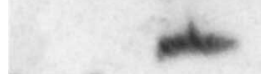

Fig. 3. Capillary blot of Smal chromosomal fragments separated by PFGE and hybridised with the 1.3-kb BamHI fragment from pUC4K. Track 1, wild-type strain Eagan; 2, mutant $401 ; 3$, mutant $366: 4$, mutant $601 ; 5$, mutant $619 ; 6$, mutant 625 .

after prolonged subculture on ribostamycin-containing agar, five of these regained the "inducible" phenotype. The remaining "non-binding" mutant (no. 366) acquired a "constitutive" phenotype after subculture. A further 29 mutants were identified that had an initial "constitutive" phenotype. These mutants retained the "constitutive" phenotype on repeated screening after subculture. One of these "constitutive" mutants (no. 401) was of particular interest because, concomitantly, it no longer reacted with type b-specific antiserum in a slide agglutination assay. Five mutants (nos. 366, 401, 601, 619 and 625) were selected for more detailed analysis. Each of these mutants showed evidence of a direct linkage between the inserted nptII gene cassette and the "constitutive" phenotype.

\section{PFGE analysis of "constitutive" insertion mutations in the transferrin-binding system}

Intact chromosomal DNA was prepared in agarose plugs from each of the selected "constitutive" transferrin-binding mutants. After digestion with Smal, the fragments were separated by PFGE, transferred to nylon membranes and hybridised with the 1-3-kb Bam HI fragment from pUC4K (corresponding to the nptII gene cassette). As the nptII cassette contains a single internal SmaI site, insertion of this
Fig. 4. Computer-generated analysis of the Smal chromosomal fragments (sizes shown in $\mathrm{kb}$ ) comprising the published map of $H$. influenzae type b strain Eagan ${ }^{17}$ and the Smal fragments generated by five "constitutive" insertion mutants. Fragments lost are designated by *; fragments showing positive hybridisation with the 1.3-kb BamHI fragment of pUC4K are in bold. Track 1, wild-type strain Eagan; 2, mutant $401 ; 3$, mutant $366 ; 4$, mutant $601 ; 5$, mutant $619 ; 6$, mutant 625 .

cassette into an existing SmaI fragment should generate two daughter fragments that hybridise with the probe although, occasionally, other Smal sites may be generated or lost accidentally at the actual site of insertion as a result of single base-pair changes during the normal recombination process. This latter process was apparent from an analysis of the hybridisation results (fig. 3) and the original Smal fingerprint (fig. 4).

The hybridisation results obtained (fig. 3) show that, as expected, no hybridisation occurred between the labelled probe and the wild-type Smal fragments obtained from strain Eagan (track 1). Two clear hybridising fragments were generated with mutants 401, 366 and 601 (tracks 2, 3 and 4), although an additional small, faint fragment of unknown origin (see above) was also visible in track 4 . With mutants 401 and 366 , the two daughter fragments correlated with loss of the same large wild-type SmaI fragment from the original gel, and this fragment, in turn, corresponded to the $330-\mathrm{kb}$ SmaI fragment (fig. 4) on the chromosome map of strain Eagan published by Butler and Moxon. ${ }^{17}$ There is some evidence in fig. 3 for faint hybridisation at the predicted position of this original large fragment, presumably resulting from incomplete restriction endonuclease digestion of the intact chromosome. In contrast, mutant 601 had lost a wild-type SmaI fragment corresponding to the $310-\mathrm{kb}$ SmaI fragment of Butler and Moxon (fig. 4), and it seems likely that this was the site of insertion of the 
nptII cassette in this mutant although, presumably for the reasons outlined above, it was not obvious how the hybridising fragments had been derived from this original fragment.

With mutant 619 (track 5), only a single small band, corresponding to the 36-kb SmaI fragment of Butler and Moxon (fig. 4), gave a positive hybridisation result with the $n p t I I$ probe, and no significant change was seen in the SmaI fingerprint compared with the wildtype strain. This indicated that the $n p t I I$ insertion must have been located close to the end of the $36-\mathrm{kb}$ fragment, thereby generating an additional very small fragment which would not be retained on the gel.

Finally, mutant 625 (track 6) generated three clear fragments that hybridised with the nptII probe, and generation of these fragments correlated with loss of the 330-kb SmaI fragment of Butler and Moxon (fig. 4). Again, it was not obvious how the hybridising fragments had been derived from the original fragment that had been lost.

Thus, of the five mutants examined, three mutants (nos. 401, 366 and 625) seemed to have insertions in the 330-kb SmaI fragment, one mutant (no. 601) had an insertion in the $310-\mathrm{kb}$ SmaI fragment, and one mutant (no. 619) had an insertion in the 36-kb SmaI fragment. These three fragments are not adjacent to each other on the chromosomal linkage map of Butler and Moxon. ${ }^{17}$

\section{Lack of homology between $H$. influenzae DNA and probes for the TBPI and TBP2 genes of \\ $N$. meningitidis}

As shared antigenic domains have been reported to exist in the TBPs of $H$. influenzae and $N$. meningitidis, an attempt was made to localise the TBP genes on the $H$. influenzae chromosome by hybridising with probes for the corresponding genes from $N$. meningitidis. However, no hybridisation was detected, even at low stringency wash conditions, either with dot-blots of total chromosomal DNA or with Smal restriction digests separated by PFGE.

\section{Discussion}

Effective stable mutagenesis caused by random transposon insertions into the $H$. influenzae chromosome has not been reported to date. However, successful insertional mutagenesis methods with no transposon involvement have been reported for several bacterial species that are naturally transformable, ${ }^{11.19}$ and while the work described in this paper was in progress, a similar procedure for $H$. influenzae was outlined, based on an artificial $2 \cdot 2-\mathrm{kb}$ DNA element consisting of the neo gene of Tn5 flanked by Haemophilus-specific uptake sequences ligated to circularised chromosomal fragments. ${ }^{20}$ The simplified procedure described in the present paper did not involve the deliberate use of specific uptake sequences, but such sequences would be expected to occur randomly on the ligated $H$. influenzae chromosome fragments at frequent intervals, as demonstrated by the fact that apparently random insertions of the nptII gene into the host chromosome were obtained readily by the simplified procedure.

Although PFGE analysis of SmaI digests of total chromosomal DNA indicated that insertions of the nptII gene cassette occurred at random sites in the host chromosome, an unexpectedly large proportion of the mutants screened (29 of 700 ) exhibited a stable "constitutive" transferrin-binding phenotype. There was no evidence from the DNA hybridisation results for an insertional "hot-spot"; the results indicated that several different chromosomal mutations could generate this phenotype. Further evidence for the complex nature of this regulatory system was provided by the observation that the six "non-binding " mutants isolated were found to have an unstable phenotype. As the $n p t I I$ insertions themselves were stable (and nontransposable), this observation indicated that secondary spontaneous mutations in the TBP regulatory system could be selected readily on continued subculture. As the lack of readily available iron is thought to constitute a major environmental signal that controls expression of numerous genes and virulence factors (in addition to iron uptake mechanisms) for many pathogens, ${ }^{21,22}$ it is perhaps not surprising that mutations at any one of a large number of loci on the $H$. influenzae chromosome may lead to a perturbation in this proposed overall regulatory system. In contrast, mutations in the TBP structural genes would be expected to be considerably rarer, and such mutations were not identified among the 700 insertions screened in the present study.

Methodology for ensuring efficient transfer of high $M_{r}$ DNA fragments from PFGE gels to membranes for non-radioactive hybridisation experiments with digoxigenin-labelled probes has not been reported previously, and considerable effort was devoted in the present study to defining gel-treatment and transfer conditions to generate reproducible hybridisation results. The method outlined here was found to produce the best results, but it is worth emphasising that UV irradiation after depurination, denaturation and neutralisation of the gel was found to be the essential step that allowed transfer to occur-presumably this step reduced the effective size of the high $M_{r}$ DNA bands immobilised in the gel and thereby ensured good transfer.

In support of the hypothesis that mutations at numerous loci may disrupt the regulatory system, detailed molecular analysis of five "constitutive" mutants showed that five different insertions of the nptII cassette had occurred, although three of these were in the same $330-\mathrm{kb} S m a \mathrm{I}$ fragment of the wildtype strain Eagan chromosome. One of these insertions had resulted concomitantly in loss of type-b capsule formation, and this observation is consistent with the fact that the $c a p b$ locus of strain Eagan has also been 
mapped to the $330-\mathrm{kb}$ SmaI fragment. This large fragment of the chromosome is of particular interest as it has been suggested that the customary association of virulence with type-b capsulation might, in part, reflect linkage between genes for type-b capsulation and genes encoding unidentified bacterial characteristics. ${ }^{23}$ Further PFGE, hybridisation and subsequent cloning experiments should enable the regulatory loci identified in the present study to be located more precisely in relation to their associated structural genes and should enable progress to be made in understanding this important regulatory mechanism. In this respect, it is worth noting that a recent study has suggested that TBPs may be regulated by levels of haemin, rather than elemental iron alone, and that haemin may be important in regulating both the iron and haemin uptake systems of $H$. influenzae. ${ }^{24}$

As an addendum to the main purpose of this study, an attempt was made to locate the TBP structural genes of $H$. influenzae with DNA probes for the TBP genes from $N$. meningitidis. The possibility of shared

\section{References}

1. Otto BR, Verweij-van Vught AMJJ, MacLaren DM. Transferrins and heme-compounds as iron sources for pathogenic bacteria. Crit Rev Microbiol 1992; 18: 217-233.

2. Tsai J, Dyer DW, Sparling PF. Loss of transferrin receptor activity in Neisseria meningitidis correlates with inability to use transferrin as an iron source. Infect Immun 1988; 56: 3132-3138.

3. Schryvers AB. Identification of the transferrin- and lactoferrinbinding proteins in Haemophilus influenzae. $J$ Med Microbiol 1989; 29: 121-130.

4. Griffiths E. Stevenson P, Ray A. Antigenic and molecular heterogeneity of the transferrin-binding protein of Neisseria meningitidis. FEMS Microbiol Lett 1990; 69: 31-36.

5. Hardie KR, Adams RA, Towner KJ. Transferrin-binding ability of invasive and commensal isolates of Haemophilus spp. J Med Microbiol 1993; 39: 218-224.

6. Morton DJ, Williams P. Siderophore-independent acquisition of transferrin-bound iron by Haemophilus influenzae type b. J Gen Microbiol 1990; 136: 927-933.

7. Schryvers $A B$. Characterization of the human transferrin and lactoferrin receptors in Haemophilus influenzae. Mol Microbiol 1988; 2: 467-472.

8. Stevenson P, Williams P, Griffiths E. Common antigenic domains in transferrin-binding protein 2 of Neisseria meningitidis, Neisseria gonorrhoeae, and Haemophilus infuenzae type b. Infect Immun 1992; 60: 2391-2396.

9. Holland J, Towner KJ, Williams P. Tn916 insertion mutagenesis in Escherichia coli and Haemophilus influenzae type b following conjugative transfer. J Gen Microbiol 1992; 138: 509-515.

10. Anderson P, Johnson RB, Smith DH. Human serum activities against Haemophilus infuenzae type b. J Clin Invest 1972; 51: $31-38$

11. Vosman B, Kok R, Hellingwerf KJ. Random insertional mutagenesis in Acinetobacter. In: Towner KJ, BergogneBérézin E, Fewson CA (eds) The biology of Acinetobacter. New York, Plenum. 1991: 183-189.

12. Vieira J, Messing J. The pUC plasmids, an M13mp7-derived system for insertion mutagenesis and sequencing with synthetic universal primers. Gene 1982; 19: 259-268.

13. Barcak GJ, Chandler MS, Redfield RJ, Tomb J-F. Genetic systems in Haemophilus infuenzae. In: Miller $\mathrm{JH}(\mathrm{ed})$ antigenic domains between the TBPs of $H$. influenzae and $N$. meningitidis ${ }^{8}$ has raised the possibility that a single vaccine could confer protection against the two major causes of bacterial meningitis. However, no DNA homology was detected with the probes, even with low stringency wash conditions. While this lack of DNA homology may result from different codon usage in the two species, the fact that anti-peptide sera prepared against the conserved $\mathrm{NH}_{2}$-terminal ends of the TBP1 and TBP2 proteins of $N$. meningitidis and $N$. gonorrhoeae also fail to react with the analogous proteins from $H$. influenzae $e^{25}$ suggests that any common epitopes may be extremely limited or be shared only by certain strains. The possibility of shared regulatory mechanisms controlling the expression of TBPs in these organisms remain to be investigated.

We are indebted to Drs K. Forbes and B. Rüger for their help and suggestions with the PFGE and hybridisation methodology, and Dr H. Palmer for the gift of pG4.2 and pSD.16. This work was supported by grants to K.J. T. from the Medical Research Council and Trent Regional Health Authority.
Methods in enzymology. San Diego, Academic Press. 1991 : 321-342.

14. Palmer HM, Powell NBL, Ala'Aldeen DA, Wilton J, Borriello SP. Neisseria meningitidis transferrin-binding protein 1 expressed in Escherichia coli is surface exposed and binds human transferrin. FEMS Microbiol Lett 1993: 110: 139-146.

15. Wilton J, Ala'Aldeen D, Palmer HM, Borriello SP. Cloning and partial sequence of transferrin-binding protein 2 of Neisseria meningitidis using a novel method: twin $\mathrm{N}$-terminal PCR. FEMS Microbiol Lett 1993; 107: 59-66.

16. Carter GI, Towner KJ, Slack RCB. Detection of TEM betalactamase genes by non-isotopic spot hybridisation. Eur $J$ Clin Microbiol 1987; 6: 406-409.

17. Butler PD, Moxon ER. A physical map of the genome of Haemophilus influenzae type b. J Gen Microbiol 1990; 136 : 2333-2342.

18. Chen WJ, Gross L, Joho KE, McAllister WT. A modified kanamycin-resistance cassette to facilitate two-codon insertion mutagenesis. Gene 1992; 111 : 143-144.

19. Labarre J, Chauvat F, Thuriaux P. Insertional mutagenesis by random cloning of antibiotic resistance genes into the genome of the cyanobacterium Synechocystis strain PCC 6803. J Bacteriol 1989; 171: 3449-3457.

20. Sharetzsky C, Edlind TD, Lipuma JJ, Stull TL. A novel approach to insertional mutagenesis of Haemophilus influenzae. J Bacteriol 1991; 173: 1561-1564.

21. Hennecke $\mathbf{H}$. Regulation of bacterial gene expression by metalprotein complexes. Mol Microbiol 1990; 4: 1621-1628.

22. Braun V, Schäffer S, Hantke K, Tröger W. Regulation of gene expression by iron. In: The molecular basis of bacterial metabolism. Berlin, Springer-Verlag. 1990: 164-179.

23. Kroll JS, Moxon ER, Loynds BM. An ancestral mutation enhancing the fitness and increasing the virulence of Haemophilus influenzae type b. J Infect Dis 1993; 168: 172-176.

24. Morton DJ, Musser JM, Stull TL. Expression of the Haemophilus influenzae transferrin receptor is repressible by hemin but not elemental iron alone. Infect Immun 1993; 61 : 4033-4037.

25. Griffiths E, Stevenson $P$, Byfield $P$ et al. Antigenic relationships of transferrin-binding proteins from Neisseria meningitidis, $N$. gonorrhoeae and Haemophilus influenzae: crossreactivity of antibodies to $\mathrm{NH}_{2}$-terminal peptides. FEMS Microbiol Lett 1993; 109: 85-92. 